\title{
The effect of dryer air temperature on fineness modulus and moisture content of cassava flour in pneumatic dryer process
}

\author{
Yus Witdarko ${ }^{1 *}$, Yosehi Mekiuw ${ }^{1}$, Ni Luh Sri Suryaningsih ${ }^{1}$, and Wahida ${ }^{1}$ \\ ${ }^{1}$ Agricultural Engineering Department, Faculty of Agriculture, Musamus University, Merauke - Indonesia
}

\begin{abstract}
One of drying method applied in flour milling industry is pneumatic drying. Various kinds of variable both dried materials and drying process condition strongly influence the quality of drying result. Fineness Modulus (FM) and Water Rate are significant variables in defining the flour quality. The aim of this study is to identify the influence of dryer air temperature on FM and Moisture Content in pneumatic dryer process condition. Both variables have sufficiently big coefficient of determination value; therefore, it can be employed to predict well the fineness modulus and water rate of the flour.
\end{abstract}

Keywords:Cassava flour, Pneumatic drying, Fineness Modulus, Moisture Content

\section{Introduction}

The increasing demand of wheat flour over years, it is expectedly substituted with kinds of flour made of local crops such as corn, cassava, and sweet potato. Flour processing technology from local crops is very limited; thus, it needs different scientific information to improve flour processing.

One crucial process in flour production is drying process. One of drying method applied in flour milling industry is pneumatic drying. Pneumatic drying is more suitable used as fast dryer to dispose water rate on material surface, because this needs short drying time (Bunyawanichakul e.t.c., 2007) [1]. Heat flow (convection) between gas and particles is very high resulting very short drying heat time (Mujamdar, 1987) [3].Various kinds of variable both dried materials and drying process condition strongly influence the quality of drying result.

\subsection{Fineness Modulus}

Several important parameter of quality requirement of flour is the level of flour fineness modulus. Fineness Modulus (FM) is an index used to show fineness level of a bulk solid material such as flour, sand, cement, and so on. Arumugan (2014) [4], FM is a factor estimated by using the result of sieve analysis. Low FM value shows fine particles and higher FM shows coarse particles.(Henderson, 1961) [3].

Fineness level is usually divided into coarse, medium, fine, which the finer the material the smaller the FM value. FM is determined based on sieving using a type of sieve with mesh or certain hole size defined and material of flour usually uses Tyler sieve. This shieve is moved by vibration resulted by vibrator machine. The result of this vibration is that the particles sieved pass down as its ability depending on particle diameter. Mathematically, Fineness Modulus of flour material can be estimated by using equation (1).

$$
F N=\frac{\text { Total of }}{\%} \frac{\text { remained cumulative }}{100}
$$

Based on this FM value, average diameter can be estimated (2)

or in unit of $\mathrm{mm}$ into

$$
D=0,0041(2)^{F M}(\text { inch })
$$

$$
\boldsymbol{D}=0,104(2)^{F M}(\mathrm{~mm})
$$

Here is stated table 1 Standard of sieve ASTM E 11 Fine Sieves type

Table1.Standard of sieve ASTM E 11 Fine Sieves type Nominal sieve opening

Standard Alternate
$\mathrm{mm}$
in

$\begin{array}{lcll}4.75 \mathrm{~mm} & \text { No.4 } & 4.75 & 0.1870 \\ 2.36 \mathrm{~mm} & \text { No.8 } & 2.36 & 0.0937 \\ 1.18 \mathrm{~mm} & \text { No.16 } & 1.18 & 0.0469 \\ 600 \mu \mathrm{m} & \text { No.30 } & 0.60 & 0.0234 \\ 300 \mu \mathrm{m} & \text { No. } 50 & 0.30 & 0.0117 \\ 150 \mu \mathrm{m} & \text { No. } 100 & 0.15 & 0.0059\end{array}$

Source :Suchorski (2007)

\subsection{Moisture Content}

In flour drying, required by BSN (BSN, 2012), that maximal final water rate is $12 \% \mathrm{wb}$ (SNI SNI-7622-2011) [5].Therefore, it is crucial to ensure that drying process 
is well-done so that it can result an effort to relate the variables of drying process and water rate of flour resulted by drying.

Generally, the aim of this study is to obtain the influence of dyer air temperature on flour fineness modulus and water rate after drying process.

\section{Research Method}

\subsection{Materials}

The main material employed for this study is white cassava obtained from Telo market, Yogyakarta as many of $200 \mathrm{~kg}$. The cassava is then peeled and cleaned manually and then grated by using grating machine. Before cassava flour is dried by using pneumatic mechanical dryier, three former research have been done namely cassava grater compression, cassava flour particle density, and the capacity of cassava flour input in each dryer.

\subsubsection{Cassava grater compression}

Compression is aimed to reduce water rate in cassava grater before pneumatic drying. Initial water rate of the flour before being pneumatically dried to be efficient should not more than $40 \% \mathrm{wb}$. To reduce moisture content, the cassava grater is compressed using hydrolic compressor machine. The result of cassava grater compression is as presented in table 2 . By observing the data of moisture content defined is of $40 \% \mathrm{wb}$, the pressure magnitude employed should be $50 \mathrm{~kg} / \mathrm{cm}^{2}$.

Table 2.Variation of compression pressure magnitude and final moisture content resulted

\begin{tabular}{|c|c|c|c|c|c|}
\hline No & $\begin{array}{c}\text { Pressure } \\
\left(\mathrm{kg} / \mathrm{cm}^{2}\right)\end{array}$ & $\begin{array}{c}\text { Final } \\
\text { weight } \\
(\mathrm{g})\end{array}$ & $\begin{array}{c}\text { Weight } \\
\text { loss } \\
(\mathrm{g})\end{array}$ & $\begin{array}{c}\text { Initial } \\
\mathrm{MC} \\
(\% \mathrm{wb})\end{array}$ & $\begin{array}{c}\text { Final } \\
\mathrm{MC} \\
(\% \mathrm{wb})\end{array}$ \\
\hline 1. & 15 & 745 & 255 & 58 & 48 \\
2. & 20 & 735 & 265 & 58 & 48 \\
3. & 25 & 725 & 275 & 58 & 47 \\
4. & 30 & 714 & 286 & 58 & 47 \\
5. & 35 & 697 & 303 & 58 & 45 \\
6. & 50 & 673 & 327 & 58 & 40 \\
\hline
\end{tabular}

Furthermore, compression is performed for each 1000 gram of grater weight 8 times with pressure $50 \mathrm{~kg} / \mathrm{cm}^{2}$ for 10 minutes. The result of compression is as stated in table 3. Average Moisture Content ( $\mathrm{MC} \% \mathrm{wb})$ obtained is $40,94 \% w b$

Table 3. MC of compression result of each 1000 gram with pressure $50 \mathrm{~kg} / \mathrm{cm}^{2}$

\begin{tabular}{|l|l|c|}
\hline No & $\begin{array}{l}\text { Water rate } \\
(\mathrm{ka} \% \mathrm{wb})\end{array}$ & $\begin{array}{c}\text { Average water rate } \\
(\mathrm{ka} \% \mathrm{wb})\end{array}$ \\
\hline 1 & 39,25 & \\
\hline
\end{tabular}

\begin{tabular}{|l|l|}
\hline 2 & 40,55 \\
\hline 3 & 42,36 \\
\hline 4 & 42,41 \\
\hline 5 & 40,35 \\
\hline 6 & 38,89 \\
\hline 7 & 42,28 \\
\hline 8 & 41,42 \\
\hline
\end{tabular}

\subsubsection{Input Capacity $\left(Q_{i}\right)$}

This research is aimed to identify input capacity on each speed variation feed screw $\left(\mathrm{V}_{\mathrm{f}}\right)$ on feeder unit. Speed variation feed screwis done by changing the comparion of diameter pulley between pulley on reducer and pulley on shaft in feed screw unit. The comparison of pulley 1:1 (60 rpm), 1:1,5 (90 rpm), 1:2 (120 rpm). Based on measurement and estimation in appendix 47 , it is obtained input capacity value as the following table 4 .

Table 4. The result of input capacity $\left(\mathrm{Q}_{\mathrm{i}}\right)$ in speed variation 60, 90, and $120 \mathrm{rpm}$ in wet flour particle diameter $\left(D_{\mathrm{pr}}\right) 0,150,0,300$, and 0,600 $\mathrm{mm}$.

\begin{tabular}{|l|c|c|c|}
\hline $\begin{array}{l}\mathrm{D}_{\mathrm{pr}} \\
(\mathrm{mm})\end{array}$ & $\begin{array}{c}\mathrm{V}_{\mathrm{f}}=60 \\
\mathrm{rpm}\end{array}$ & $\begin{array}{c}\mathrm{V}_{\mathrm{f}}=90 \\
\mathrm{rpm}\end{array}$ & $\mathrm{V}_{\mathrm{f}}=120 \mathrm{rpm}$ \\
\hline 0.600 & 0.0362 & 0.0488 & 0.0579 \\
\hline 0.300 & 0.0371 & 0.0509 & 0.0616 \\
\hline 0.150 & 0.0230 & 0.0344 & 0.0478 \\
\hline
\end{tabular}

Compressed cassava grater is destroyed. The result of wet flour is then sieved with sieve in 30 mesh $(0,60 \mathrm{~mm})$, 50 mesh $(0,30)$ and $100 \operatorname{mesh}(0,15 \mathrm{~mm})$ used as the treatment of remained wet flour particle size in 50 mesh $(0,30 \mathrm{~mm})$. Further process is drying the flour by using pneumatic drying method constructed in twice the drying process to fulfill one requirement of Indonesian National Standard of flour which is water rate should be maximum of $12 \% \mathrm{wb}$.

\subsection{Instrument}

The main instrument used in this study is pneumatic dryer which can be seen in Fig 1. Several main parts of this instrument is heat treatment furnace of dryer with LPG as the fuel using high pressure burner located horizontally in the furnace. Blower absorbs heat from the furnace and distributes it to drying pipe as long as nine meters. The rate and flow of air can be adjusted by setting up the width of furnace inlet opening. The input of materials to be dried is performed through a feeder completed with blower which pushing to drying pipe. Drying process occurs along the drying pipe channel and to separate between heat and dry flour is completed in cyclone installed in the end of the dryer pipe. 


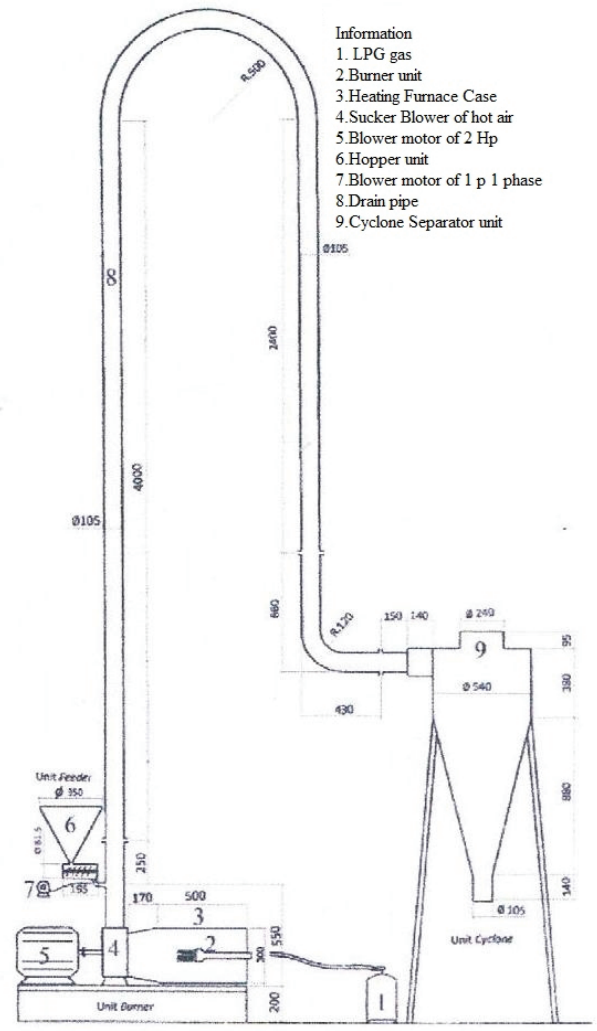

Fig 1.Pneumatic Dryer

\section{Research Procedures}

The research is begun with turning the dryer on, then after the dryer temperature reaches the defined value, the materials of cassava grater which have been compressed and sieved are put into the dryer machine. The flour is then collected by using a container under the cyclone. The treatment is performed including dryer air flow speed of $18,1 \mathrm{~m} / \mathrm{s}$, diameter of grate material to be used is the remained flour in the sieve of 80 mesh.According to Stoess (1983) [6], the amount of flour belongs to fine materials. The sample of wet flour has average water rate of $40,94 \% \mathrm{wb}$, the variation of dryer air temperature of $145^{\circ} ; 160^{\circ}$; and $175^{\circ} \mathrm{C}$. Furthermore, the flour sieved is dried by using pneumatic dryer in drying cycle twice.

\subsection{Dryer air temperature testing on Fineness Modulus}

Flour Fineness Modulus testing is performed by flour sampling from dried flour cycle 1 and 2 so that the flour with $\mathrm{Ka}$ is according to Indonesian National Standard wich is maximum of $12 \% \mathrm{wb}$. The speed of screw feeder is $60 \mathrm{rpm}$. Testing procedures are as follows: (1) Preparation of pneumatic dryer with dryer air speed $18,10 \mathrm{~m} / \mathrm{s}$, cassavas to be dried are as many as 250 gram, (2) Turn the blower on and measure the temperature in dryer pupe with variation $145{ }^{\circ} \mathrm{C}, 160{ }^{\circ} \mathrm{C}, 175{ }^{\circ} \mathrm{Cusing}$, (3) Pour the cassava with moisture content around rate $40 \%$ wb into Hopper inlet (4) Weigh the dried flour mass with digital scale then record the mass decrease. (5) FM is determined by sieving using Tyler sieve with 30,50 , and $100 \mathrm{mesh}$. This sieve is moved with vibration resulted by vibrator machine.

\subsection{Air temperature testing on water rate}

Flour Fineness Modulus testing is performed by flour sampling from dried flour cycle 1 and 2 so that the flour with MC is according to Indonesian National Standard wich is maximum of $12 \% \mathrm{wb}$. The speed of screw feeder is $60 \mathrm{rpm}$. Testing procedures are as follows: (1) Preparation of pneumatic dryer with dryer air speed $18,10 \mathrm{~m} / \mathrm{s}$, cassavas to be dried are as many as 250 gram, (2) Turn the blower on and measure the temperature in dryer pupe with variation $145^{\circ} \mathrm{C}, 160{ }^{\circ} \mathrm{C}, 175^{\circ} \mathrm{C}$ using, (3) Pour the cassava with water rate around $\mathrm{r} 40 \% \mathrm{wb}$ into Hopper inlet (4) Weigh the dried flour mass with digital scale then record the mass decrease. (5)Sieving (6) Flour sample is baked with temperature $105^{\circ} \mathrm{C}$ with duration of 22 hours.

\section{Results And Discussion}

Based on the data collected during the research and the estimation result of FM value, it is obtained the influence of dryer air temperature on FM presented in Table 2 .

Table 2. The influence of dryer air temperature on Fineness Modulus

\begin{tabular}{ccccc} 
Variation & \multicolumn{5}{c}{$F M$} \\
Treatment & \multicolumn{5}{c}{ Average } \\
\cline { 2 - 5 }$\left(\mathrm{T}_{\mathrm{u}}\right)$ & 1 & 2 & 3 & \\
& & & & 1,483 \\
$145^{\circ} \mathrm{C}$ & 1,485 & 1,480 & 1,485 & 1,344 \\
$160^{\circ} \mathrm{C}$ & 1,352 & 1,312 & 1,367 & 1,140 \\
$175^{\circ} \mathrm{C}$ & 1,149 & 1,127 & 1,146 &
\end{tabular}

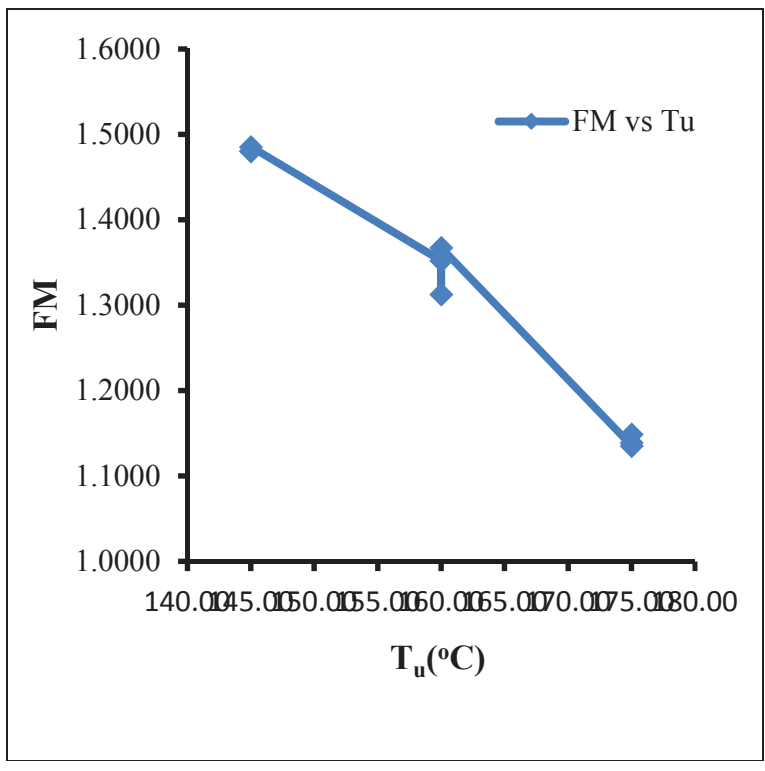

Fig. 3. Graphic of Influence of $\mathrm{T}_{\mathrm{u}}$ on $F M$

The influence of dryer air temperature on FM can be seen on Fig. 3. FM will tend to decrease opposite to the 
increase of dryer air temperature. This shows that by increasing dryer air temperature, the flour will be finer (lower FM). This condition is caused by the higher the dryer air temperature the greater the ability of dryer to vaporize the water in the material, the flour particles will be more disheveled.

According to the data collected during the research and estimation result (appendix 13) and the estimatin of water rate in the end of observation (appendix 51), then it is obtained the relationship between $\mathrm{Ka}$ and several particles studied as presented in Table 3 .

Table 3. Variation of dryer air temperature on water rate in cycle 1 and 2

\begin{tabular}{|c|c|c|c|c|c|}
\hline \multicolumn{2}{|l|}{$145^{\circ} \mathrm{C}$} & \multicolumn{1}{|l|}{$160^{\circ} \mathrm{C}$} & $175^{\circ} \mathrm{C}$ & \\
\hline Cycle 1 & Cycle 2 & Cycle 1 & Cycle 2 & Cycle 1 & $\begin{array}{c}\text { Cycle } \\
2\end{array}$ \\
\hline 24,07 & 11,85 & 22,46 & 10,21 & 14,95 & 4,55 \\
\hline 24,46 & 11,89 & 22,01 & 10,24 & 15,22 & 4,65 \\
\hline 23,51 & 11,72 & 21,61 & 10,44 & 15,29 & 4,47 \\
\hline 23,70 & 11,78 & 21,33 & 10,31 & 15,36 & 4,68 \\
\hline 23,67 & 12,30 & 22,53 & 10,57 & 15,38 & 4,63 \\
\hline 23,58 & 12,38 & 22,58 & 10,43 & 15,09 & 4,41 \\
\hline
\end{tabular}

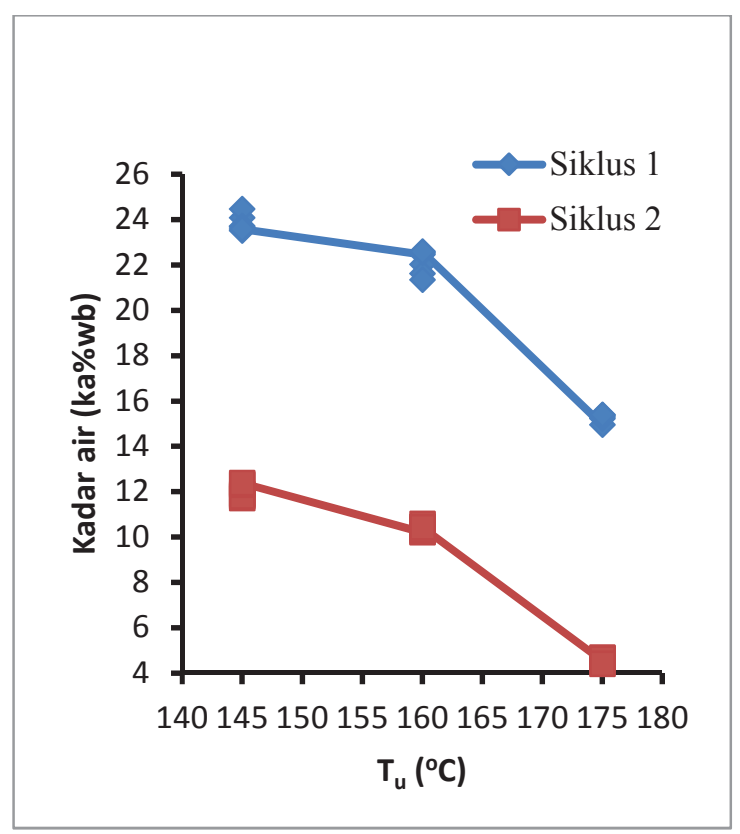

Fig. 4.Graphic of influence of $\mathrm{Tu}(\mathrm{oC})$ on $\mathrm{Ka}(\% \mathrm{wb})$

In Fig. 4 cycle 1 dryer shows that on temperature $175^{\circ} \mathrm{C}$ the increase of heat transfer from air to material is greater compared to temperature 145 and $160^{\circ} \mathrm{C}$. This condition produces less water ratefrom the material. Meanwhile, in cycle 2 dryer shows that on temperature $160^{\circ} \mathrm{C}$ heat transfer increases from air to material compared to it is on temperature $160^{\circ} \mathrm{C}$ in cycle 1 . Whereas on temperature $1750 \mathrm{C}$ heat transfer decreases from air to material compared to it is on temperature $175 \mathrm{oC}$ in cycle 1 .

The higher the dryer air temperature, it shows that the temperature difference between material and dryer air is greater and greater. The greater the difference between material and dryer air temperatures, it increases heat transfer from air to material. The higher the heat transfer, the bigger the ability to vaporize water from material, so that it decreases water rate of material to be dried.

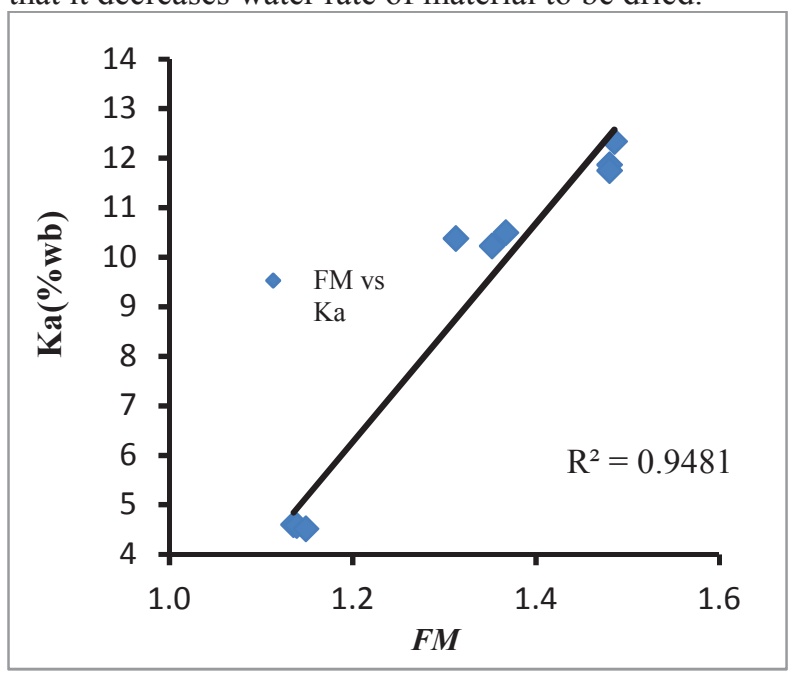

Fig 5.Graphic of Relationship of FM to MC

Fig. 5 shows that the higher the water rate is followed by increasing FM value. In this study, the flour before it is dried with water rate $40,94 \%$ wbis visually clotting because of flour processing indluence in feed screw. The flour will spread in the dryer pipe where heat and dryer air result water rate in the flour to decrease and the flour will spread (not sticky) so that it will establish fineness level value (Fineness Modulus). Stable dryer air speed and various air temperature influence FM and Ka of the flour. In other words, the more course FM has bigger water rate compared to fine FM which has smaller water rate.

\section{Conclusion}

Based on the research, it can be concluded that dryer air temperature in pneumatic drying process strongly influences Fineness Modulus and water rate of the flour. Pneumatic drying on dryer air temperature $160^{\circ} \mathrm{C}$ with 2 dryer cycles produce water $10,36 \% \mathrm{wb}$ has fulfilled one requirement of Indonesian National Standard for flour water rate maximum of $12 \% \mathrm{wb}$.

\section{References}

[1] Bunyawanichakul, P., Walker, G.J., Sargison, J.E. and Doe, P.E. .Modelling and simulation of paddy grain (rice) drying in a simple pneumatic drying. Journal of Biosystem Engineering 96,3 (2007)

[2] Henderson, S.M., Feed grinding studies. Basic observations and challenges on grinding procedure. Journal of Agricultural Engineering 42: 350-352, 364 (1961) 
[3] Mujumdar, A.S.. Handbook of Industrial Drying.Marcel Dekker, Inc., New York and Basel(1987)

[4] Arumugan, Effect of specific gravity on aggregate varies the weight of concrete cube. SSRG Internasional Journal Civil Engineering (SSRG-IJCE)1,3(2014)

[5] Badan Standardisasi Nasional (2012), SNI-76222011, SNI tepung mocaf http://www.sisni.bsn.go.id/index.php/sni m ain/sni/detail sni/10942 (2012)
[6] Stoess,H.A.JR.PE., Pneumatic Conveying, $2^{\text {nd }}$, Edn, A Wiley-Intercience Publication, John Wilay and Sons, New York (1983)

[7] Suchorski, D.M., Aggregates for Conrete. ACI Education Buletin E1-07, ACI Commitee E701, Forming Hills,MI(2007) 